\title{
Psychological and Behavioural Consistency Value Seeking of Tourists in Niche Tourism: Nostalgia, Authenticity Perception, and Satisfaction
}

\author{
Jieling Zhou' \\ Keheng Xiang ${ }^{2,3}$ \\ Qian Cheng' \\ Cao Yang ${ }^{4}$
}

'School of Tourism and Urban-Rural Planning, Zhejiang Gongshang University, Hangzhou, 310018, People's Republic of China; ${ }^{2} \mathrm{School}$ of Hotel and Tourism Management, The Hong Kong Polytechnic University, Kowloon, 999077, Hong Kong, Special Administrative Region of China; ${ }^{3}$ Zhejiang Technical Institute of Economics, Hangzhou, 310018, People's Republic of China; ${ }^{4}$ China Tourism Academy, Beijing, 100008, People's Republic of China

Correspondence: Keheng Xiang Email keheng.xiang@connect.polyu.hk

\begin{abstract}
Introduction: This study proposed a model based on Izard's theory of differential emotions to examine the effects of heritage nostalgia on perceived authenticity towards tourist satisfaction and the moderation of self-congruity in Chinese niche tourism.

Methods: We examined descriptive statistics to obtain an overview of the sample by using computer program SPSS 22. Then, for evaluation, partial least squares structural equation modelling (PLS-SEM) was employed as the appropriate statistical tool, and the statistical approach was implemented using the Smart PLS 3.0 computer program.

Results: The results of partial least squares structural equation modelling showed that heritage nostalgia positively affects existential and object-based authenticity. Existential and object-based authenticity positively influences tourist satisfaction. Self-congruity positively moderates the relationship between existential or object-based authenticity and heritage nostalgia.

Conclusion: The linkage mechanism of tourists' psychology and behavior in heritage tourism has been explored, the internal mechanisms such as heritage nostalgia, tourists' authenticity and tourists' satisfaction have been discovered, and the internal mechanism of tourists' consistency of psychology and behavior has also been explained.
\end{abstract}

Keywords: heritage nostalgia, perceived authenticity, tourist satisfaction, self-congruity, niche tourism

\section{Introduction}

Heritage tourism motivates people to experience different symbols and items of the past at tourist destinations. ${ }^{1}$ It provides the experience of continual transformation occurring in the developing relationship between cultural heritage and tourism. ${ }^{2}$ Cultural heritage is developed in accordance with a specific scale of meanings and values. $^{3}$ Diverse cultural heritages, which stimulate the development of various tourism products and heritage destinations, attract tourists. ${ }^{4,5}$ Some heritage attractions are major tourist destinations having universal significance; other heritage attractions are fashioned for special interest groups, which results in niche tourism creation. ${ }^{6,7}$ Therefore, niche tourism is a segment of the tourism industry that provides small tourism destinations and specific products. These destinations are visited for adventures, different experiences, and religious reasons. ${ }^{8-10}$

In cultural heritage tourism, particularly in niche tourism, the meanings, images, and values of a heritage site are more decisive than the intrinsic value of the site, ${ }^{3,11}$ which results in a puzzling relationship between the perceived value and emotion. ${ }^{12-15}$ Some 
studies have identified the relationship among nostalgia, authenticity, and satisfaction in cultural tourism. ${ }^{16-21}$ However, most previous studies in cultural heritage tourism domains did not sufficiently differentiate types of nostalgia. From psychological perspective, nostalgia usually comprises both cognitive and emotional reactions. ${ }^{22}$ Different emotions induced from nostalgic experiences tend to influence people's behaviour differently, ${ }^{23}$ and this nature of nostalgia with complicity highlights the importance of conceptualising and measuring the nostalgia of tourism by utilising a multidimensional approach. $^{24}$

Chi and Chi (2020) first conceptualised and developed a three-dimensional scale to measure vicarious or historical nostalgia evoked by heritage tourism and examined a proposed theoretical framework by using the data collected in America and China. Their study demonstrated that heritage tourists utilise historical nostalgia to satisfy their needs for seeking authenticity, which can significantly influence their satisfaction and revisit intention. Moreover, their findings offered profound contributions to the tourism industry and nostalgia literature. However, they used only wellknown historical sites with universal significance, such as the Statue of Liberty in America and the Great Wall in China, and a research gap remained in the niche tourism domain. They called for further studies investigating tourists' historical nostalgia in other context when exploring other nostalgia elements in heritage tourism. This paper responds to this call and attempts to bridge the research gap. ${ }^{24}$

In this study, a research model based on Izard's differential emotion theory and literature review was proposed, and a fourdimensional scale was first developed to measure heritage nostalgia evoked by niche heritage tourism. The measurement items of heritage nostalgia were adapted from Jain et al (2019) and were modified according to Chinese cultural settings. Moreover, self-congruity was included as a moderating variable because the degree of congruity is likely to influence the emotions and perceived value. ${ }^{14,29}$ The current understanding of the relationship between emotions and cognition was expanded from the perspective of heritage tourists, and the moderating influence of self-congruity on the relation between heritage nostalgia and perceived authenticity was explored at niche heritage sites. The main contributions of this paper are as follows:

1. We investigated cognitive-affective variables towards the experience of tourists during niche tourism.

2. We explored the mediating effects of authenticity between heritage nostalgia and satisfaction.
3. We confirmed the moderating effects of selfcongruity on niche heritage tourism.

The reminder of this paper is organised as follows: In the literature review and theoretical framework section, the theoretical basis is provided for this study and relevant research hypotheses are proposed. The research method module provides the case and research process. The findings verify the research hypothesis through the quantitative research, and finally this paper presents the theoretical and practical contributions.

\section{Literature Review and Theoretical Framework \\ Izard's Theory of Differential Emotions}

Izard's theory of differential emotions has been a critical concept of emotional cognition since the 1970s. It is used to study the interactions between the emotional states of people and cognitive processes ${ }^{25}$ and has its roots in psychology, which emphasises the emotions and indicates the importance of cognitive variables. ${ }^{26}$ According to Izard's theory, emotions decide not only the cognitive directivity and selectivity of an individual but also their subsequent actions. ${ }^{27}$ Thus, Izard's theory presents a satisfactory theoretical background to investigate the effects of heritage nostalgia on perceived authenticity towards the satisfaction of tourists in heritage tourism.

The study framework followed three steps of Izard's theory of differential emotions. First, the emotion comes directly from the stimulation of the neural-evaluative component of an emotion by the internal and external environment. ${ }^{25,28}$ In niche heritage tourism, nostalgia is involuntarily stimulated in tourists as physiological response to particular states. Second, emotions can influence people's cognition processes, that is, the nostalgia of tourists affects the perceived authenticity related to their existential experiences or objects. Third, according to Izard's theory, interactions between a particular emotion patterns and cognition lead to novel emotional experiences. ${ }^{28}$ In this scenario, tourist satisfaction is influenced because of interactions between perceived authenticity and nostalgia.

\section{Heritage Nostalgia and Perceived Authenticity}

Heritage nostalgia is a reflection of the past comprising a combination of emotions and memories, which can be passed on and shared through groups of people. ${ }^{23,30}$ 
Nostalgia was previously perceived as a feeling of sickness because it led to remembrance and sorrow, and the only treatment for it was a revisit or repatriation. ${ }^{31}$ Holak and Havlena (1998) revealed that emotion complexity led to a nostalgic practice, and researchers have reported contrary societal influences. Smeekes (2015) showed how national nostalgia is likely to be associated with optimistic in-group directions. ${ }^{32}$ Therefore, nostalgia is regarded as the desire to revisit apparently perfect bygone days and demands memory stimulation and longing for positive and negative situations, such as those evoking cosiness, warmth, and sorrow. ${ }^{33}$

In psychological and marketing domains, nostalgia is commonly conceptualised as an emotion-related construct that comprises both contradictory emotions and cognitive reactions. ${ }^{22}$ Nostalgia can be categorised into personal and vicarious or historical nostalgia. ${ }^{23,34}$ Personal nostalgia is associated with a person's memory, which can be evoked by an object or event experienced by the person. ${ }^{35}$ Vicarious or historical nostalgia is unrelated to the person's experience or living memory, which can be evoked by a heritage object or historical event. ${ }^{23}$ Therefore, historical nostalgia is closely associated with and facilitated by heritage tourism, ${ }^{24}$ and small groups of people may share the heritage nostalgia evoked by an object or event in an unusual environment of niche heritage attractions.

The unusual environment refers to an environment outside of people's daily life, study and work (including natural and cultural environments). In this environment, the psychological and behavioural characteristics of tourists easily tend to be abnormal. ${ }^{36,37}$ Tourists with historical nostalgia vary in age, and multiple age groups experience the influence of nostalgia. This effect is wellrecognised. ${ }^{38-40}$ Since 2003, researchers have confirmed the positive effects of nostalgia on tourism. For example, nostalgia is a powerful motivator and leads to an increase in the marketing capacity of tourism organisations. ${ }^{39,41-44}$ Moreover, nostalgia benefits the overall experience of tourists. $^{45,46}$ Specifically, nostalgia addresses the emotional associations of tourists with places and other elements, which are important characteristics in heritage tourism. ${ }^{47}$ Studies have indicated nostalgia to be connected with the perceived authenticity of cultural heritage sites. For instance, Vesey and Dimanche (2003) stated that "in destinations related to heritages, tourists desire the history via pictures of what they believe the history was like". Kulczycki and Hyatt (2005) reported that staged authenticity is important to heritage and nostalgia experiences of tourist.

Authenticity is the quality of being "real" and "authentic" or "genuine and real". ${ }^{38,48}$ Scholars have proposed authenticity as an intangible asset, and authenticity is the perspective or value perceived by witnesses of a location or product. ${ }^{49,50}$ However, philosophers have sustained a long-lasting interest in authenticity involving a practice and feeling. ${ }^{51}$ From the philosophical perspective, authenticity is a projection of how real a person is to themselves in balancing the rational and emotional self. ${ }^{43}$ In heritage tourism, authenticity is often connected to substances, locations, attractions, and emotions. ${ }^{52}$ As a special trait, authenticity is innately discovered within objects such as products, events, cultures, and places and is presented as external to visitors. ${ }^{53,54}$

Authenticity is related to either objects or visitor experience, ${ }^{55}$ which is objective or subjective, respectively. In terms of objects, authenticity is considered a scientific or historical object, which is either original or perfectly imitative, ${ }^{41}$ whereas in terms of visitor experience, authenticity is conceptualised as the existential, mutual process of understanding - supporting the perception that visitors positively construct their own significance by negotiating different environmental elements. ${ }^{56}$ Wang (1999) and Reisinger and Steiner (2005) have widely analysed different methods and understandings of the perceived authenticity. ${ }^{57,58}$ Wang (1999) used several techniques in three major categories: objective, constructive, and existential. Objective and constructive categories concern physical products, and the existential category is connected to tourists' experience. According to Wang, objective and constructive categories can coexist to form object-based authenticity. For the existential category, Wang utilised the existential method to describe tourists' activities.

Tourist nostalgia can trigger judgments regarding perceived authenticity and match their current circumstances to past experiences. ${ }^{59}$ Some tourists prefer to visit specific tourism sites to relive their past and learn about their heritage. ${ }^{60}$ Therefore, for people, in addition to providing experiences such as relaxation, fun, diversion, and traditional food taste, heritage tourism spots have become places to experience the "good old days". ${ }^{59}$ Researchers have regarded nostalgia as an optimistic mindset regarding the past; however, nostalgia is accepted as emotional response. ${ }^{61-66}$ Previous studies have shown the relation between nostalgia motivation and perceived authenticity. ${ }^{13,15,67}$ Both nostalgia motivation and perceived authenticity are determined using bygone practices concerning people, experiences, or circumstances, and the positive relations between object-based or existential authenticity and 
nostalgia are endorsed in other settings. ${ }^{68,69}$ Therefore, the hypotheses adopted are as follows:

H1. Heritage nostalgia positively influences object-based authenticity.

H2. Heritage nostalgia positively influences existential authenticity.

\section{Relationship Between Perceived Authenticity and Tourist Satisfaction}

Authenticity leads to a drastic increase in the perceived satisfaction of tourists, ${ }^{70}$ and perceived satisfaction is essential to evaluate destination goods, tourist attractions, and services. ${ }^{71,72}$ Del Bosque and Martín (2008) defined satisfaction as the cognitive-affective state of an individual developed from the visitor's activities. ${ }^{73}$ Studies on tourist satisfaction have employed overall perceived performance and expectation-disconfirmation models. ${ }^{74-78}$ According to the expectation-disconfirmation model, tourists hold expectations before they experience or purchase things. If the outcome of tourists exceeds their anticipation, positive disconfirmation is achieved, which results in consumer satisfaction. ${ }^{76}$ Researchers have reported that in heritage tourism, the perception of tourists about authenticity rather than actual authenticity contributes to satisfaction. ${ }^{79}$

Authenticity is a crucial precursor of tourist satisfaction and a key element that affects the overall evaluation of tourists. ${ }^{54,80}$ Nguyen and Cheung (2016) acknowledged the direct effect of authenticity as a single variable on the satisfaction of cultural heritage tourist. In cultural heritage tourism studies, authenticity has been investigated as a single variable or as authenticity with double object-based and existential dimension. ${ }^{81}$ Girish and Chen (2017) and Nguyen and Cheung (2016) have proven the explicit effect of authenticity as the single variable on cultural heritage tourist satisfaction, and Lee et al (2016) analysed the immediate effects of authenticity on satisfaction as a double (object-based and existential) variable. ${ }^{19,82,83}$ We considered that the authenticity dual dimension is highly comprehensive and can provide considerable information regarding actual correlations among the analysed variables. Therefore, the investigation of whether our data can prove the individual positive effect of the dual dimensions of authenticity on satisfaction is meaningful. Based on the aforementioned references and literature, the following hypotheses are proposed:

H3. Object-based authenticity positively influences tourist satisfaction.
H4. Existential authenticity positively influences tourist satisfaction.

Furthermore, according to the hypothesis of the direct influence of heritage nostalgia on object-based and existential authenticity and of object-based and existential authenticity on tourist satisfaction, when object-based and existential authenticity is improved, heritage nostalgia can positively affect tourist satisfaction. This phenomenon indicates that object-based and existential authenticity can play a mediating role in the relationship of heritage nostalgia with tourist satisfaction. The proposed study hypotheses of the mediating effect are as follows:

H5: Object-based authenticity presents a mediating effect between heritage nostalgia and tourist satisfaction.

H6: Existential authenticity presents a mediating effect between heritage nostalgia and tourist satisfaction.

\section{Moderating Effect of Self-Congruity}

Self-congruity refers to the extent to which the self-image of a consumer matches to the personality of a user of a typical brand. Self-image is a person's subjective feeling and viewpoint regarding themselves. ${ }^{84}$ According to self-congruity theory, people hold several thoughts about themselves and behave accordingly to strengthen their self-image. ${ }^{29}$ Therefore, people are likely to buy products or services in line with their original self-concept to achieve self-consistency. ${ }^{29}$ People are aware of what they would like to be and what they are. A study confirmed the relation between self-congruity and customer emotions. ${ }^{29}$ In their study on "lounge user" behaviour at the airport, Lee et al (2016) stated that self-congruity leads to the drastic generation of cognitive value awareness and positive emotional responses for revisit intention. The gaming field proofs validated the positive relation between self-congruity and customer emotions. ${ }^{29}$

Self-congruity, as a cognitive matching process, considerably influences the emotional experience produced in a certain purchasing situation, as shown in hospitality studies. ${ }^{29,85}$ Cognitive and emotional experiences are different, but they interact with mental processes. ${ }^{29}$ This indicates that nostalgia, as an emotion, is related to tourist self-congruity. For instance, a positive emotional experience of nostalgia and image congruity can lead to an increase in tourists' perceived nostalgia. Congruity, the degree of self-image matching of a person to the image of the tourism destination, may lead to different selfcongruity-processing styles. ${ }^{86}$ Similarly, tourism spot categorisation entails a small generalisation of previous emotions, 


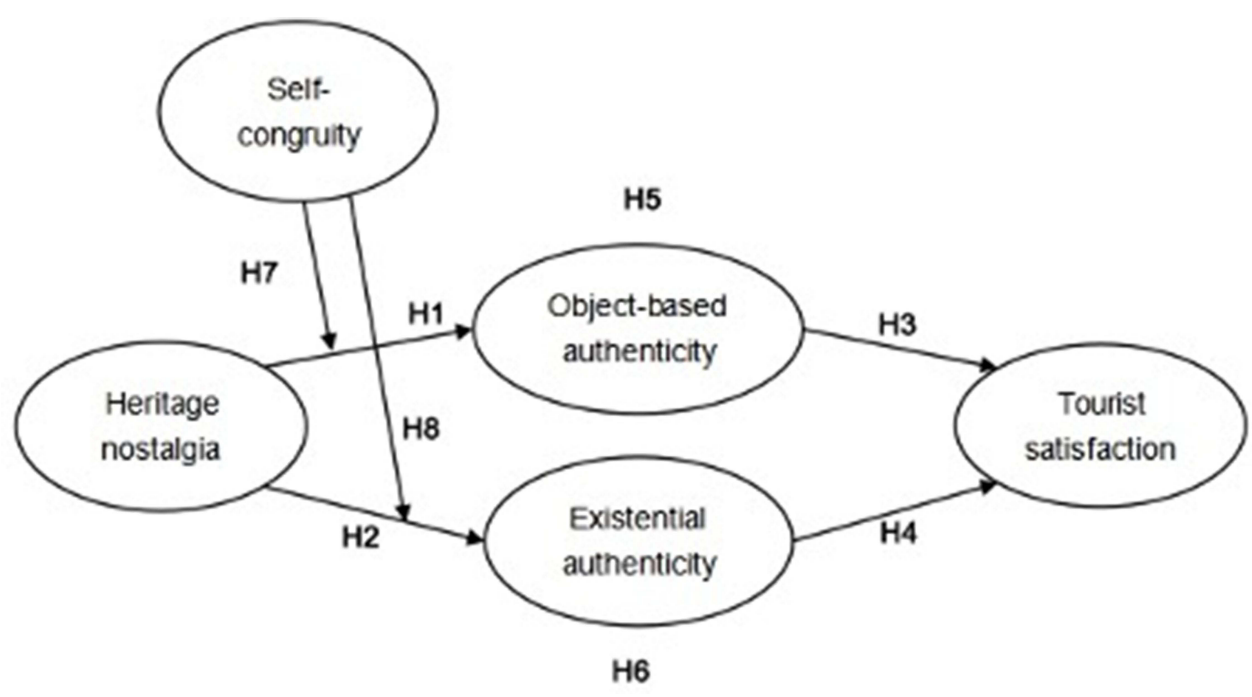

Figure I Research model.

such as nostalgia, towards the experiences of tourists. Thus, high self-congruity influences the state of mind of tourists in their perceived authenticity judgments. Based on selfcongruity theory, we proposed that the relationship of heritage nostalgia with perceived authenticity is moderated through perceived self-congruity.

H7. Self-congruity moderates the relationship of objectbased authenticity with heritage nostalgia.

H8. Self-congruity moderates the relationship of existential authenticity with heritage nostalgia.

\section{Research Framework}

The properties of five constructs are proposed. These constructs include an exogenous variable (heritage nostalgia), three endogenous variables (existential authenticity, objectbased authenticity, and tourist satisfaction), and a moderator (self-congruity). The exogenous and endogenous variables of the constructs are measured with "formative" and "reflective" indicators, respectively, which are associated with "cause" and "effect" classification. ${ }^{87}$ Figure 1 illustrates the proposed research model.

\section{Research Design and Methods Research Case}

Five cultural heritage destinations (Figure 2) from the Zhejiang province of China were selected in this study. Zhejiang holds importance as the birthplace of the ancient philosophy of mind and behaviour or neo-Confucianism, which represents "the essence of Chinese civilisation" and "the Chinese Renaissance". ${ }^{88}$ It is also the hometown of the first Chinese Nobel Prize winner for medicine, Ms. Tu Youyou, who coined a cure for malaria from a traditional herbal remedy by studying hundreds of old manuscripts while searching for ancient wisdom. Because in China, Zhejiang plays a role with increasing importance in the development of heritage tourism, and its niche attractions are more appealing than those of often crowded destinations (considering the prevention of COVID-19 spread), we selected five cultural heritage destinations from five counties of the Zhejiang province (Liu Ji Temple in Wenchen, Kunqu Opera in Yongjia, Guci Lyric in Ruian, Lounge Bridge in Taishun, and Bowl Kiln Village in Cangnan) as the study fields.

The Wencheng county is named after an ancient literary magnate, Liu Ji's posthumous title "Wencheng", and Liu Ji Temple is a traditional Chinese building with an architectural style, which is substantially integrated with the natural landscape and cultural heritage (Figure 2A).

The Yongjia county has a history that spans over 1800 years and preserves the oral and intangible cultural heritage of "Kunqu Opera in Yongjia" (Figure 2B). Ruian is the originating place of "Guci Lyric", a type of ballad singing in the local dialect with a drum rhythm, which can be traced back to the Qing dynasty (Figure 2C). The Taishun county was founded in the Ming dynasty (1452) with many ancient "lounge bridges", which are roofed Chinese wooden bridges constructed using exquisite technology (Figure 2D). The Bowl Kiln village in the Cangnan County is known as "a living museum" of ancient porcelain manufactures (Figure 2E). According to the authors, each attraction is a niche cultural heritage site associated with spiritual, moral, methodological, objective, and 


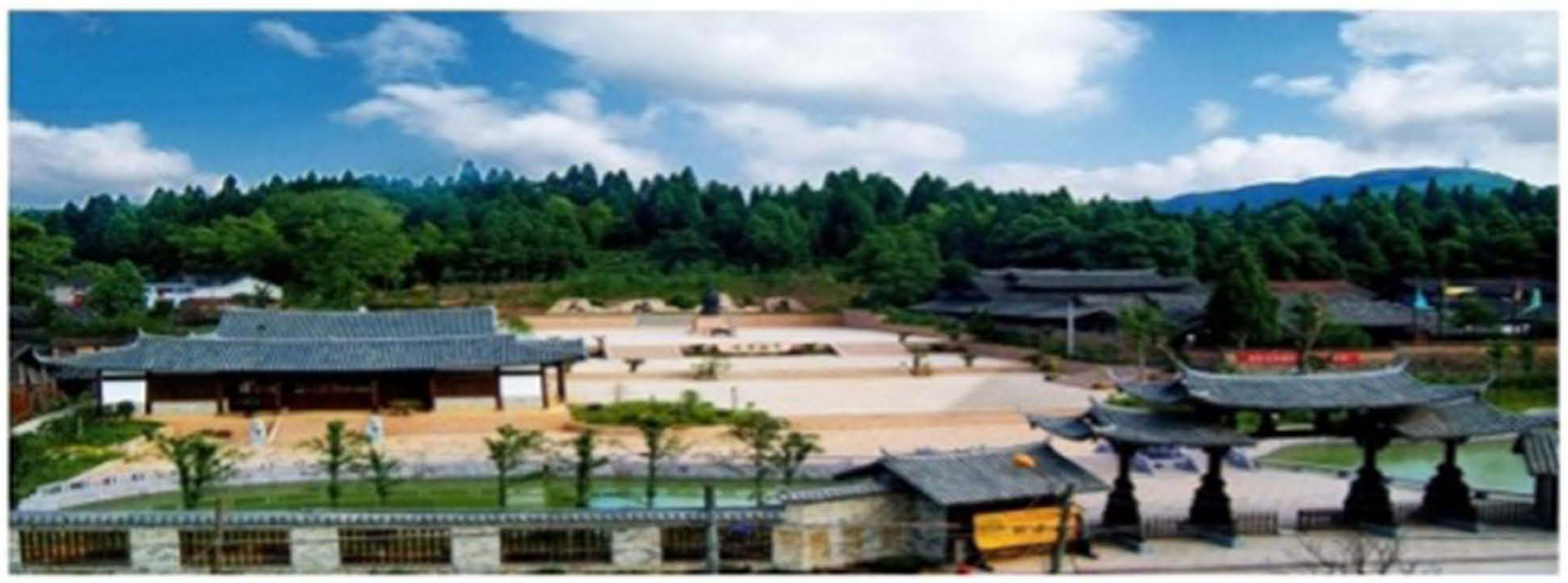

A Liu Ji Temple in Wencheng

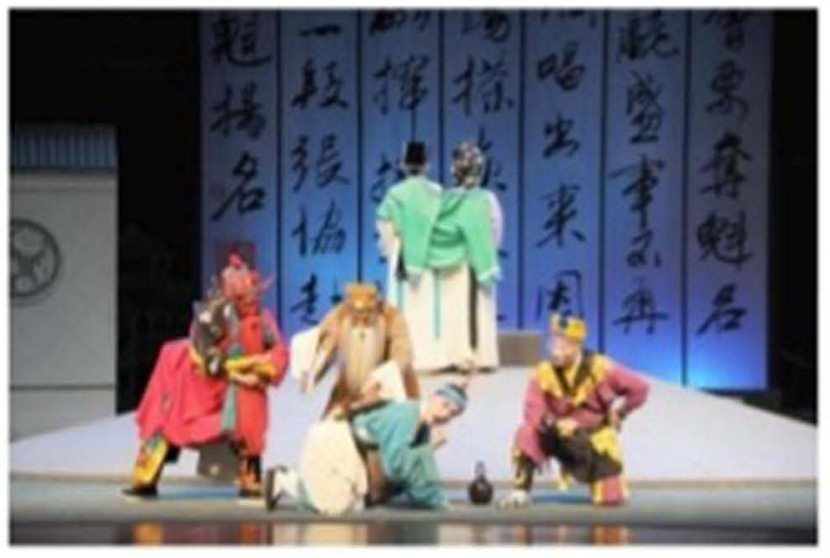

B Kunqu Opera in Yongjia

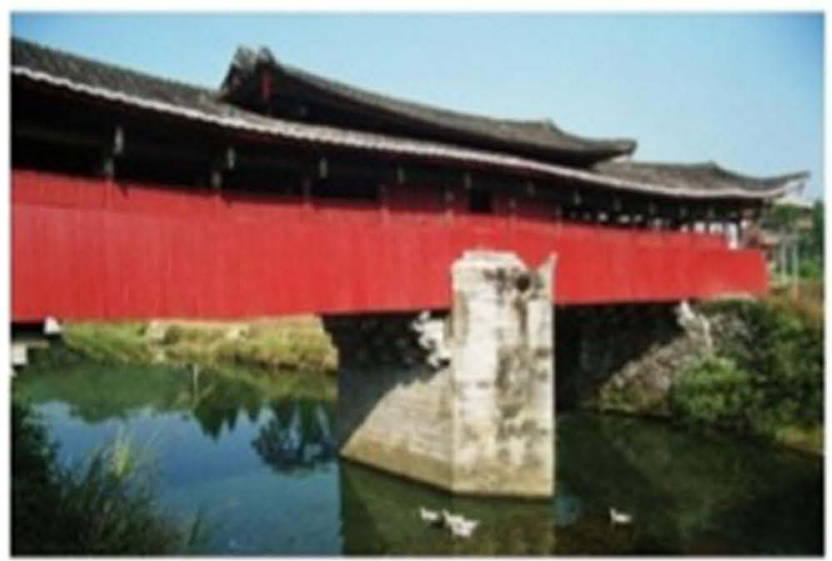

D Lounge Bridge in Taishun

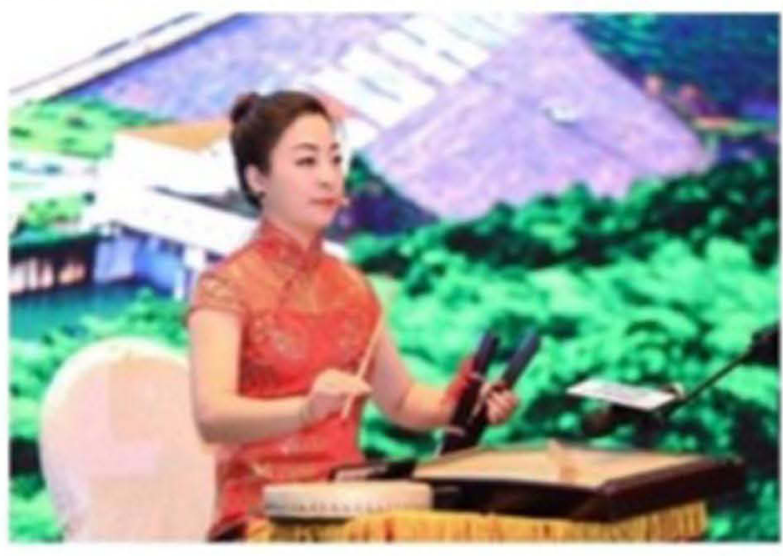

C Guci Lyric in Ruian

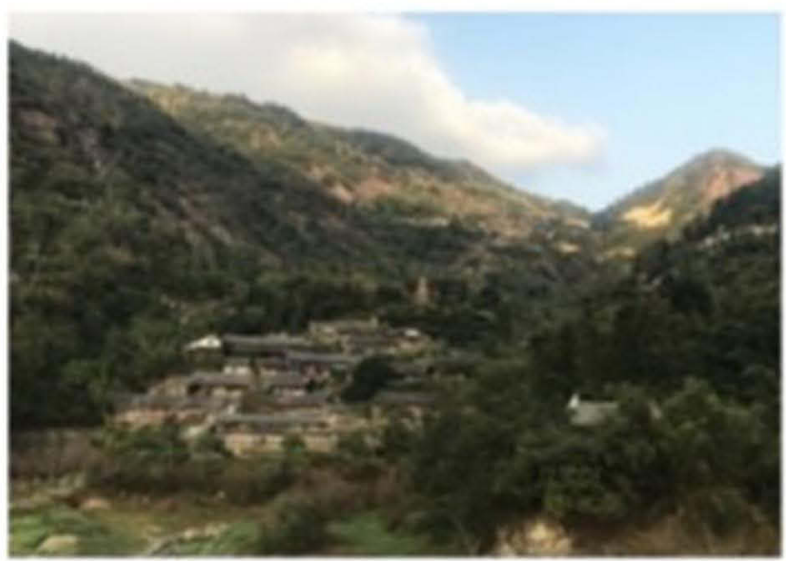

E Bowl KinVillage in Cangnan

Figure 2 Cultural heritage destinations (A-E). Source: Self-employed. 
subjective characteristics, which are usually observed and cherished by small groups of people but are often ignored by others.

\section{Research Method}

First, the researchers examined descriptive statistics to obtain an overview of the sample by using computer program SPSS 22. Then, for evaluation, partial least squares structural equation modelling (PLS-SEM) was employed as the appropriate statistical tool, and the statistical approach was implemented using the Smart PLS 3.0 computer program.

This study adopted PLS-SEM for three reasons. First, the proposed model comprises reflective and formative variables, and the model with the second-order formative constructs can be tested by employing the two-step approach. Thus, PLS-SEM is a suitable approach for the data treatment because it can handle both reflective and formative second-order constructs. ${ }^{89,90}$ Second, PLS-SEM not only presents the advantage of mathematical calculations but also is conducive to solving problems with a minimal demand for the sample size. For example, it allows samples of 200 or fewer cases. ${ }^{91}$ Finally, PLS-SEM is applicable to the moderation analysis, ${ }^{92}$ which enables theoretical exploration and verification.

\section{Measurement Scales}

Heritage nostalgia was measured using items adapted from the study of Jain et al (2019). Considering Chinese cultural settings, heritage nostalgia measurement items were categorised into four dimensions: past imagery, positive emotions, negative emotions, and collective nostalgia. All these dimensions were formative indicators. Authenticity items were measured by considering the specific context of a particular cultural heritage site. The authenticity variable was measured from a double perspective by following the study of Kolar and Zabkar (2010). Four and six items exist in object-based and existential authenticity, respectively. These items were designed to illustrate reflective indicators. Tourist satisfaction was evaluated as cognitive judgement obtained from the experiences of tourists after their stay at the destination. ${ }^{93}$ We selected six items as loading factors for measurements. These items were designed to illustrate reflective indicators. The self-congruity construct was measured with the items adapted from the studies of Sirgy and Su (2000) and Das (2014) and was modified according to the cultural heritage context. ${ }^{94,95}$ All the item statements of construct measurements used the seven-point
Likert scale $(1=$ strongly disagree, $2=$ disagree, $3=$ moderately disagree, $4=$ neutral, $5=$ moderately agree, 6 $=$ agree, $7=$ strongly agree).

\section{Data Collection and Sampling}

The data were collected in 2020 during the field study at five cultural heritage sites. The data collection process was organised as a part of the Zhejiang Heritage Tourism Research Project in the autumn (low) and summer (high) seasons. Both the holiday and cultural tourists visit the study area in these two seasons. The study sample for testing the proposed model included Chinese tourists, who visited any of these five heritage sites. In this study, questionnaires were distributed at the exits of relevant scenic spots through convenience sampling. A total of 250 questionnaires were released in this study. After incomplete and invalid questionnaires were removed from the returned questionnaires, 204 questionnaires were finally used for analysis, with an effective rate of $81.6 \%$.

\section{Results}

\section{Descriptive Statistics}

A total of 204 (valid) travellers participated in this survey during the investigation period of 6 weeks (Table 1). The proportion of male adults was approximately $54 \%$. Among all the participants, the largest group constituted people under the age of 30 years, comprising $34.8 \%$ of the sample, and the second-largest group was aged between 41 and 50 years. Overall, $65.2 \%$ of the participants were unmarried. Most participants held bachelor's degrees (79.9\%), and the largest group had a monthly income of 5001-10,000 RMB.

\section{Analysis of Scale Reliability and Validity}

Fornell and Larcker (1981) and Nunnally (1978) have suggested several standards to evaluate convergence validity as follows: the factor loading, composite reliability, average of variance extracted (AVE), and Cronbach's $\alpha$ should exceed $0.7,0.7,0.5$, and 0.7 , respectively. Moreover, $\mathrm{R}^{2}$ and path coefficients were majorly referenced to explain the study model. ${ }^{96,97}$ The $\mathrm{R}^{2}$ values of $0.19,0.33$, and 0.67 in a PLS path model were described as weak, moderate, and substantial, respectively, by Chin (1998a, p. 323) and were associated with reflective indicators. Table 2 presents the statistical data analysis results obtained using PLS-SEM. When the factor loading of an 
Table I Profile of Respondents

\begin{tabular}{|c|c|c|c|}
\hline Characteristic & Valid $\mathbf{N}$ & $\begin{array}{l}\text { Valid } \\
\text { Percent }\end{array}$ & $\begin{array}{l}\text { Cum. } \\
\text { Percent }\end{array}$ \\
\hline $\begin{array}{l}\text { Gender (valid } \mathbf{N}=\mathbf{2 0 4} \text { ) } \\
\text { Male } \\
\text { Female }\end{array}$ & $\begin{array}{l}110 \\
94\end{array}$ & $\begin{array}{l}53.9 \\
46.1\end{array}$ & $\begin{array}{l}53.9 \\
100.0\end{array}$ \\
\hline $\begin{array}{l}\text { Age }(\text { valid } \mathbf{N}=204) \\
30 \text { years old or less } \\
3 \mid-40 \text { years } \\
4 \mid-50 \text { years } \\
5 \mid \text { years or above }\end{array}$ & $\begin{array}{l}71 \\
46 \\
58 \\
29\end{array}$ & $\begin{array}{l}34.8 \\
22.5 \\
28.5 \\
14.2\end{array}$ & $\begin{array}{l}34.8 \\
57.3 \\
85.8 \\
100.0\end{array}$ \\
\hline $\begin{array}{l}\text { Marriage (valid N = 204) } \\
\text { Unmarried } \\
\text { Married }\end{array}$ & $\begin{array}{l}133 \\
71\end{array}$ & $\begin{array}{l}65.2 \\
34.8\end{array}$ & $\begin{array}{l}65.2 \\
100.0\end{array}$ \\
\hline $\begin{array}{l}\text { Education (valid } \mathbf{N}=\mathbf{2 0 4} \text { ) } \\
\text { High school } \\
\text { University } \\
\text { College } \\
\text { Postgraduate and above }\end{array}$ & $\begin{array}{l}9 \\
31 \\
132 \\
32\end{array}$ & $\begin{array}{l}4.4 \\
15.2 \\
64.7 \\
15.7\end{array}$ & $\begin{array}{l}4.4 \\
19.6 \\
84.3 \\
100.0\end{array}$ \\
\hline $\begin{array}{l}\text { Employment (valid } \\
\mathbf{N}=\mathbf{2 0 4} \text { ) } \\
\text { Farmer } \\
\text { Business staff } \\
\text { Civil servant or public } \\
\text { Institution } \\
\text { Soldier, Armed Police or } \\
\text { Public Security } \\
\text { Student } \\
\text { Culture staff or teachers } \\
\text { Private or individual workers }\end{array}$ & $\begin{array}{l}2 \\
35 \\
109 \\
2 \\
41 \\
7 \\
8\end{array}$ & $\begin{array}{l}1.0 \\
17.2 \\
53.4 \\
1.0 \\
\\
20.1 \\
3.4 \\
3.9\end{array}$ & $\begin{array}{l}1.0 \\
18.2 \\
71.6 \\
72.6 \\
92.7 \\
96.1 \\
100.0\end{array}$ \\
\hline $\begin{array}{l}\text { Monthly Income (valid } \\
\text { N = 204) } \\
\text { Under 2000 RMB } \\
\text { Between 200I-5000 RMB } \\
\text { Between 500I-I0,000 RMB } \\
\text { Above I0,00I RMB }\end{array}$ & $\begin{array}{l}39 \\
38 \\
98 \\
29\end{array}$ & $\begin{array}{l}19.1 \\
18.6 \\
48.1 \\
14.2\end{array}$ & $\begin{array}{l}19.1 \\
37.7 \\
85.8 \\
100.0\end{array}$ \\
\hline
\end{tabular}

item was $<0.7$, the item was deleted. This deletion led to an increase in the average variance extraction and composite reliability. The scale item of "collective nostalgia": "I would like others to also experience what I am feeling right now" was deleted because its factor loading did not attain the specified standards.

For other scale items, the factor loading was between 0.783 and 0.967 . The $\mathrm{R}^{2}$ values of existential authenticity, objectbased authenticity, and tourist satisfaction were $0.434,0.436$, and 0.719 , respectively, which were moderate and substantial. For "past imagery", "positive emotion", "negative emotion", "collective nostalgia", "object-based authenticity", "existential authenticity", and "tourist satisfaction", the Cronbach's $\alpha$ values were $0.929,0.913,0.918,0.863,0.942,0.944$, and 0.978 , respectively, and the composite reliability (CR) values were $0.946,0.940,0.942,0.917,0.958,0.956$, and 0.982 , respectively. The average variance extractions (AVE) were within $0.779-0.899$. These statistical analysis results confirmed that the study model presents high convergent validity. At the level of second-order construct, we obtained the parameter estimates for the significance of weight (t-value), indicator weight, and variance inflation factor (VIF). The recommended indicator weight was $>0.2,{ }^{98}$ and for VIF, the common acceptable threshold was $<3.33 .{ }^{99}$ VIF value were $<3.33$, and hence, the results did not pose a multi-collinearity problem (Table 2). Table 2 presents these results.

Because for negative emotions, the indicator weight was only 0.006 , which is less than the significance threshold of 0.2 , this indicator was excluded from the model discriminant validity test. For the discriminant validity of the PLS model, the AVE value of each construct must be $>0.5$, and the AVE square root must be larger than the coefficient value of each construct pair. ${ }^{97}$ In our model (excluding negative emotions), all the AVE values and AVE square roots satisfied the discriminant validity requirements. Table 3 presents the results.

\section{Path Coefficients and Mediating Analysis}

PLS is used to determine if the path coefficient is significant by following the re-sample procedure for $t$-testing. We adopted bootstrapping ${ }^{98}$ as the resampling method. Table 4 presents the $\mathrm{t}$-value verification results. Hypothesis $\mathrm{H} 1$ is true $(\beta=0.660, \mathrm{t}=$ $11.432>1.96$, and $p<0.001$ ); hence, heritage nostalgia positively influences object-based authenticity. Hypothesis $\mathrm{H} 2$ is true $(\beta=0.659, \mathrm{t}=11.224>1.96$, and $\mathrm{p}<0.001)$; thus, heritage nostalgia positively influences existential authenticity. Hypothesis $\mathrm{H} 3$ is true $(\beta=0.297, \mathrm{t}=3.329>1.96$, and $\mathrm{p}<$ 0.001 ); hence, object-based authenticity positively influences tourist satisfaction. Hypothesis $\mathrm{H} 4$ is true $(\beta=0.583, \mathrm{t}=6.515$ $>1.96$, and $\mathrm{p}<0.001$ ); therefore, existential authenticity positively influences tourist satisfaction.

Table 5 presents the mediating effects of perceived authenticity. Hypothesis $\mathrm{H} 5$ is true (the indirect effect is 0.196 , and $\mathrm{p}<0.001$ ), and hypothesis $\mathrm{H} 6$ is true (the indirect effect is 0.384 , and $p<0.001$ ). Figure 3 presents the results of the structural model.

\section{Moderating Effects of Self-Congruity}

The moderating effects of self-congruity were verified using hypotheses $\mathrm{H} 7$ and $\mathrm{H} 8$. Based on the path coefficient analysis, Table 6 and Figure 4 present the analysis results 
Table 2 Analysis of Scale Reliability and Convergence Validity

\begin{tabular}{|c|c|c|c|c|c|c|}
\hline Construct and Scale Item & Mean & SD & Loading & Cronbach's $\alpha$ & CR & AVE \\
\hline Past imagery & & & & 0.929 & 0.946 & 0.779 \\
\hline Many memories & 5.48 & 1.332 & 0.859 & & & \\
\hline A lot of thoughts & 5.40 & 1.284 & 0.893 & & & \\
\hline Coming images & 5.30 & 1.391 & 0.893 & & & \\
\hline Bygone days & 5.08 & 1.498 & 0.872 & & & \\
\hline Relieved moment & 5.30 & 1.370 & 0.859 & & & \\
\hline Positive emotions & & & & 0.913 & 0.940 & 0.796 \\
\hline Joy & 5.47 & 1.193 & 0.925 & & & \\
\hline Pleasant & 5.35 & 1.233 & 0.939 & & & \\
\hline Calm & 5.33 & 1.218 & 0.908 & & & \\
\hline Relaxed & 5.48 & 1.197 & 0.944 & & & \\
\hline Negative emotions & & & & 0.918 & 0.942 & 0.802 \\
\hline Pain & 2.98 & 1.349 & 0.893 & & & \\
\hline Anxiety & 3.00 & 1.711 & 0.783 & & & \\
\hline Melancholy & 3.12 & $\mathrm{I} .744$ & 0.931 & & & \\
\hline Regret & 3.57 & $\mathrm{I} .78 \mathrm{I}$ & $0.84 I$ & & & \\
\hline Collective nostalgia & & & & 0.863 & 0.917 & 0.786 \\
\hline Sharing feeling with family & 5.35 & 1.602 & 0.876 & & & \\
\hline Sharing feeling with friends & 5.15 & 1.337 & 0.851 & & & \\
\hline Community memories & 5.17 & 1.475 & 0.931 & & & \\
\hline Object-based authenticity & & & & 0.942 & 0.958 & $0.85 I$ \\
\hline Architecture impression & 5.50 & 1.090 & 0.913 & & & \\
\hline Peculiarities of interior design & 5.53 & 1.052 & 0.937 & & & \\
\hline Attractive historical town & 5.71 & 1.056 & 0.931 & & & \\
\hline Heritage information & 5.62 & 1.037 & 0.908 & & & \\
\hline Existential authenticity & & & & 0.944 & 0.956 & 0.784 \\
\hline Arrangements connected & 5.78 & 1.029 & 0.859 & & & \\
\hline Insight into the historical era & 5.70 & 1.020 & 0.909 & & & \\
\hline Related history and legends & 5.60 & 1.076 & 0.918 & & & \\
\hline Religious \& spiritual experience & 5.63 & 1.063 & 0.928 & & & \\
\hline Peaceful atmosphere & 5.68 & 1.019 & 0.887 & & & \\
\hline Human history and civilization & 5.52 & 1.142 & 0.804 & & & \\
\hline Tourist satisfaction & & & & 0.978 & 0.982 & 0.899 \\
\hline Overall satisfied & 5.56 & 1.060 & 0.950 & & & \\
\hline Happy with this visit & 5.61 & 1.080 & 0.952 & & & \\
\hline Feel right in choosing site & 5.54 & 1.089 & 0.967 & & & \\
\hline Glad to visit heritage area & 5.56 & 1.079 & 0.923 & & & \\
\hline Delighted to see the heritage & 5.56 & 1.101 & 0.949 & & & \\
\hline Feel happy for experience & 5.55 & 1.084 & 0.947 & & & \\
\hline Self-congruity & & & & 0.928 & 0.944 & 0.740 \\
\hline The cultural heritage's value are regularly communicated to me & 5.35 & 1.200 & 0.866 & & & \\
\hline We view ourselves as partners in charting the direction of cultural heritage & 5.15 & 1.332 & 0.917 & & & \\
\hline The image of cultural heritage is consistent with how I see myself & 5.17 & 1.205 & 0.918 & & & \\
\hline $\begin{array}{l}\text { The successor of the cultural heritage are congruent with how I would like to } \\
\text { see myself }\end{array}$ & 5.00 & 1.292 & 0.851 & & & \\
\hline The successor of the cultural heritage are mirror image of me & 4.73 & 1.344 & 0.766 & & & \\
\hline I am quite similar to the typical tourists of this heritage tourism & 5.08 & 1.284 & 0.833 & & & \\
\hline
\end{tabular}

(Continued) 
Table 2 (Continued).

\begin{tabular}{|c|c|c|c|c|c|c|}
\hline Construct and Scale Item & Mean & SD & Loading & Cronbach's $\alpha$ & CR & AVE \\
\hline Second-order formative constructs & \multicolumn{3}{|c|}{ First-order constructs } & Weights & $\mathrm{t}$-value & VIF \\
\hline \multirow[t]{4}{*}{ Heritage nostalgia } & \multicolumn{3}{|c|}{ Past imagery } & $0.497 * * *$ & 27.837 & 2.151 \\
\hline & \multicolumn{3}{|c|}{ Positive emotions } & $0.400 * * *$ & 24.318 & 2.256 \\
\hline & \multicolumn{3}{|c|}{ Negative emotions } & 0.006 & 0.111 & 1.101 \\
\hline & \multicolumn{3}{|c|}{ Collective nostalgia } & $0.27 I^{* * *}$ & 16.727 & 1.462 \\
\hline
\end{tabular}

Note: $* * * p<0.001$.

Table 3 Discriminant Validity

\begin{tabular}{|l|l|l|l|l|l|}
\hline & EXA & OBA & TSA & PIM & PEM \\
\hline Existential authenticity (EXA) & $\mathbf{0 . 8 8 5}$ & & & & \\
Object-based authenticity (OBA) & 0.836 & $\mathbf{0 . 9 2 2}$ & & & \\
Tourist satisfaction (TSA) & 0.832 & 0.785 & $\mathbf{0 . 9 4 8}$ & & \\
Past imagery (PIM) & 0.560 & 0.563 & 0.577 & $\mathbf{0 . 8 8 3}$ & \\
Positive emotions (PEM) & 0.560 & 0.552 & 0.577 & 0.695 & $\mathbf{0 . 8 9 2}$ \\
Collective nostalgia (CNO) & 0.572 & 0.580 & 0.557 & 0.494 & 0.520 \\
\hline
\end{tabular}

Note: Bold figures on the diagonal are the square roots of AVE values.

Table 4 Path Coefficients Analysis

\begin{tabular}{|l|l|l|}
\hline Hypothesis & Path Coefficients & t-Statistics \\
\hline HI: Heritage nostalgia $\rightarrow$ Object-based authenticity & 0.660 & $11.432^{* * *}$ \\
H2: Heritage nostalgia $\rightarrow$ Existential authenticity & 0.659 & $11.224^{* * *}$ \\
H3: Object-based authenticity $\rightarrow$ Tourist satisfaction & 0.297 & $3.329 * * *$ \\
H4: Existential authenticity $\rightarrow$ Tourist satisfaction & 0.583 & $6.515^{* * *}$ \\
\hline
\end{tabular}

Note: ***Represents $p<0.001$.

Table 5 Mediating Effects of Perceived Authenticity

\begin{tabular}{|l|l|l|}
\hline Hypothesis & Effect & p-value \\
\hline $\begin{array}{l}\text { H5: Heritage nostalgia } \rightarrow \text { Object-based } \\
\text { authenticity } \rightarrow \text { Tourist satisfaction } \\
\begin{array}{l}\text { H6: Heritage nostalgia } \rightarrow \text { Existential } \\
\text { authenticity } \rightarrow \text { Tourist satisfaction }\end{array}\end{array}$ & 0.196 & 0.000 \\
\hline
\end{tabular}

of moderating effects. Hypothesis $\mathrm{H} 7$ is true $(\beta=1.257$, $\mathrm{t}=2.086>1.96$, and $\mathrm{p}<0.05),(95 \%$ CI $[0.051,2.463])$. Self-congruity moderates the relationship between objectbased authenticity and heritage nostalgia. The high and low levels of self-congruity strengthen and weaken, respectively, the positive relationship between objectbased authenticity and heritage nostalgia (Figure 4A). Hypothesis $\mathrm{H} 8$ is true $(\beta=1.403, \mathrm{t}=2.626>1.96, \mathrm{p}<$ $0.01),(95 \%$ CI: $[0.335,2.471])$. Self-congruity moderates the relation between existential authenticity and heritage nostalgia. The high and low levels of self-congruity strengthen and weaken, respectively, the positive relationship between existential authenticity and heritage nostalgia (Figure 4B).

\section{Discussion and Conclusion}

\section{Conclusion}

Based on Izard's theory of differential emotions and literature review, this study investigated the impact of heritage nostalgia on tourists' perception of authenticity towards satisfaction and the moderating role of selfcongruity in niche tourism. Heritage nostalgia has a positive impact on existential authenticity and objectbased authenticity, which highlights the importance of positive emotions for matching tourists' authenticity perception. Existential authenticity and object-based authenticity positively influence tourist satisfaction, and the positive emotions of tourists can be significantly 


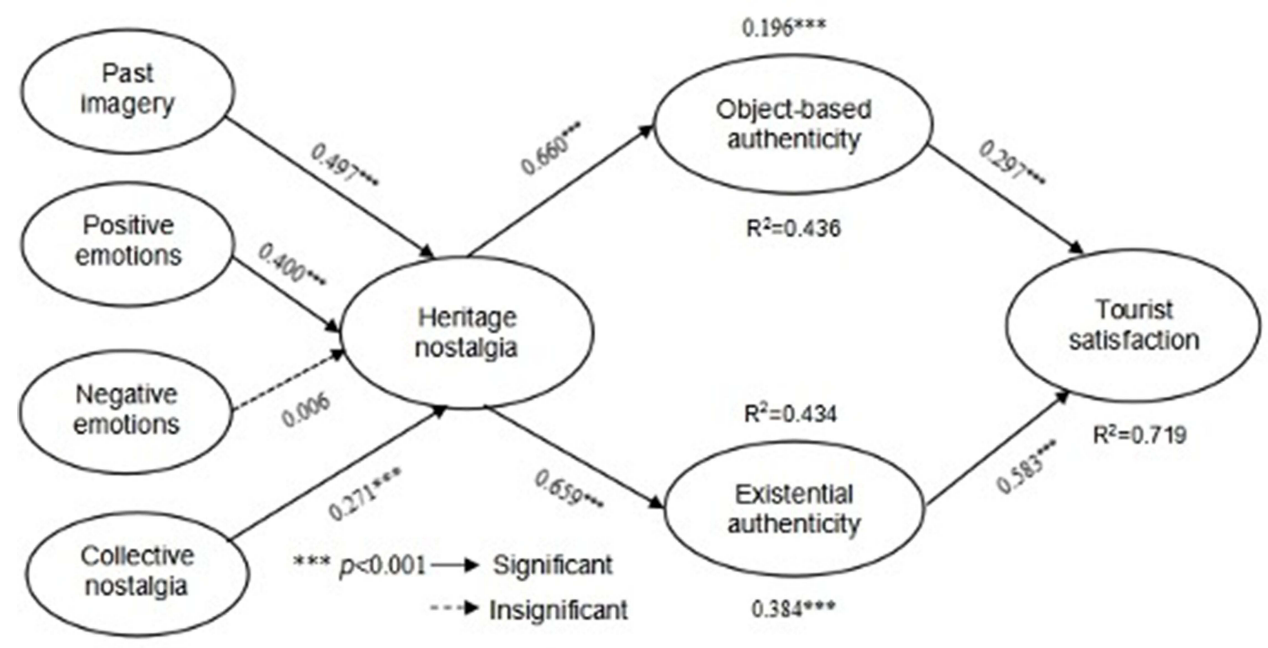

Figure 3 Results of the structural model.
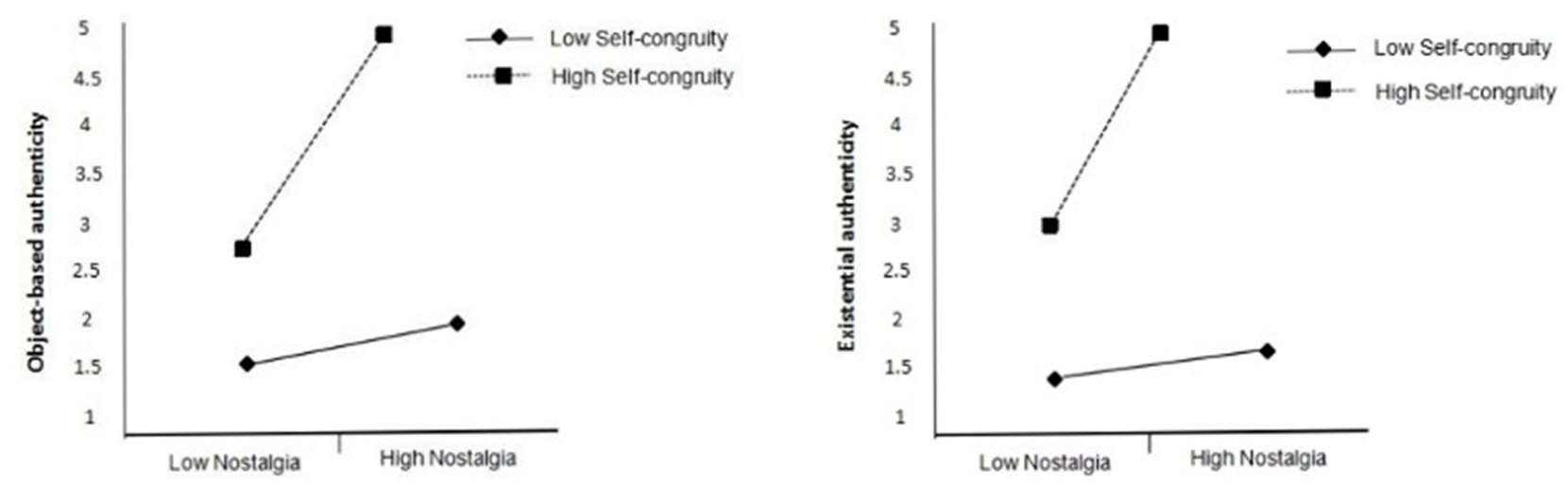

A

B

Figure 4 Moderating effects of self-congruity. (A) Moderating effects of self-congruity on the relationship between heritage nostalgia and object-based authenticity. (B) Moderating effects of self-congruity on the relationship between heritage nostalgia and existential authenticity.

strengthened. Moreover, tourists lacking positive emotions are susceptible to fatigue and cognitive difficulty during heritage tourism. Self-congruity can moderate the relation between heritage nostalgia and object-based or existential authenticity for bridging tourists' self-consistency. In the context of niche heritage tourism, the differential positive emotions of heritage nostalgia can improve the psychological and behavioural consistency of tourists through two dimensions of authenticity perception, which in turn contribute to tourists' satisfaction.

\section{Theoretical Contribution}

This study examined the effects of heritage nostalgia on perceived authenticity towards tourist satisfaction and the moderation of self-congruity for niche heritage tourism.
Some outcomes agreed with the results of previous studies as follows:

(i) The study model revealed that heritage nostalgia significantly influences authenticity. The findings indicated that tourists with higher heritage nostalgia perceived higher authenticity regarding cultural heritage sites. The outcomes are partially in line with the results of previous studies, such as Smith and Campbell (2017), which reported the direct influence of nostalgia on perceived authenticity. ${ }^{100}$ (ii) Concentrating on the research model, connections indicated that heritage nostalgia leads to high levels of satisfaction, meditated through existential and object-based authenticity, among tourists, and existential authenticity plays a stronger mediating role than objectbased authenticity. (iii) This study revealed a significant 
Table 6 Moderating Effects of Self-Congruity

\begin{tabular}{|l|l|l|l|l|}
\hline Hypothesis & Coefficients & BootLLCI & BootUICI & t-Statistics \\
\hline H7: Heritage Nostalgia* Self-congruity $\rightarrow$ Object-based authenticity & 1.257 & 0.051 & 2.463 & $2.086^{*}$ \\
H8: Heritage Nostalgia* Self-congruity $\rightarrow$ Existential authenticity & 1.403 & 0.335 & 2.471 & $2.626^{* *}$ \\
\hline
\end{tabular}

Notes: *Represents $p<0.05$; **Represents $p<0.01$.

association that reflected a positive effect of perceived authenticity on tourist satisfaction. This finding is in line with the literature reports. ${ }^{20}$

Moreover, this study confirmed the moderating influence of self-congruity on the relationship between existential or object-based authenticity and heritage nostalgia. From the methodological perspective, this study applied a novel mediated and moderated model. The model demonstrated "interesting relationships" in heritage tourism that have not been examined in other studies, and thus, can highly comprehensively contribute to the discovery of factors leading to niche heritage tourism development.

\section{Managerial Implication}

The study results widely and practically contributed to managerial implications. First, the results showed that heritage nostalgia positively affects existential and object-based authenticity. Thus, heritage nostalgia should be actively cultivated in niche heritage tourism. To engage tourists who are highly prone to nostalgia, tourist product designers can employ customised advertisement with the scenery of old places and old pictures and other approaches to develop a nostalgic atmosphere. ${ }^{101}$ Tourism authorities must retain the characteristics of ancient cultural settings to maintain a simple and beautiful ecological environment to well preserve both the tangible and intangible attraction heritage to trigger the tourists' heritage nostalgia.

Second, because perceived existential and object-based authenticity play a mediating role between tourist satisfaction and heritage nostalgia and positively affect tourist satisfaction, tourism managers should protect the integrity of authentic heritage by developing the historical allusions, folk songs, and folk customs and by properly preserving traditional architectures, local cultures, and historical landmarks to provide a true picture. ${ }^{102}$ Moreover, these managers must encourage local craftsmen to demonstrate their creation process so that the tourists can experience the culture and history and advertise dynamic charms of niche heritage. ${ }^{47}$ These charms may include local cuisine and traditional festivals. Because existential authenticity more strongly affects tourist satisfaction than object-based authenticity, tourism managers are encouraged to use culture plus modern technologies, such as virtual and augmented reality technologies. ${ }^{46}$

Finally, because the relationship of heritage nostalgia with existential or object-based authenticity is positively moderated through self-congruity, tourism managers must plan to satisfy expectations concerning similarities between tourists' self-congruity and the cultural heritage value. Consequently, tourism authorities must provide settings that agree with tourists' experiences of the excitement, sincerity, and communication of cultural heritage by exploring related cultural and gastronomic events with faithful and comprehensive information. Moreover, tourists can interact with locals and experience their traditions and customs through different activities, such as ceramic making and singing folk songs with local residents. This practice can enhance the quality of visitors' authentic perceptions and allow them to develop nostalgia during their excursions.

\section{Limitations and Future Research}

This study presents several limitations. First, all the heritage sites selected for investigation are situated in China's Zhejiang province. Future studies should employ this model to examine whether the findings differ with places. Second, the used sample size satisfies PLS path modelling requirements; however, future studies can target a large sample size for relatively better validation. Finally, in-depth studies based on the proposed model must obtain an approach to attract many heritage tourists, such as testing the samples according to age to determine whether there is a significant difference among multiple age groups.

\section{Ethics Statement}

We declare that participants in our research study allow us to use their data for academic research and publication. All the participants were anonymous and their data was protected. All the programs in our research study were approved by the Institutional Review Board of Zhejiang Gongshang University, all participants provided informed consent to take part in this study, in accordance with the Declaration of Helsinki. 


\section{Author Contributions}

All authors made substantial contributions to conception and design, acquisition of data, or analysis and interpretation of data; took part in drafting the article or revising it critically for important intellectual content; agreed to submit to the current journal; gave final approval of the version to be published; and agree to be accountable for all aspects of the work.

\section{Funding}

Soft Science Research Program of Science and Technology Department of Zhejiang, China (2021C35059), Philosophy and Social Science Planning Special Project of ZheJiang Province (20GXSZ26YB) Excellent Scientific research Team Fund Project of Zhejiang Technical Institute of Economics(JKY2021011, JKY2021012) .

\section{Disclosure}

The authors declare that they have no conflicts of interest in this work.

\section{References}

1. Ka Leong DC. Heritage or hesitate? Preserving authenticity in Hong Kong tourism. Int J Tour Sci. 2016;16(4):191-202. doi:10.1080/15980634.2016.1233647

2. Waitt G. Consuming heritage: perceived historical authenticity. Ann Tour Res. 2000;27(4):835-862. doi:10.1016/S0160-7383(99) 00115-2

3. Corsale A. Jewish heritage tourism in Bucharest: reality and visions. Geogr J. 2017;183(3):261-271. doi:10.1111/geoj.12211

4. Castro CB, Armario EM, Ruiz DM. The influence of market heterogeneity on the relationship between a destination's image and tourists' future behaviour. Tour Manag. 2007;28(1):175-187. doi:10.1016/j.tourman.2005.11.013

5. Ma M, Hassink R. An evolutionary perspective on tourism area development. Ann Tour Res. 2013;41:89-109. doi:10.1016/j. annals.2012.12.004

6. McKercher B. Towards a classification of cultural tourists. Int J Tour Res. 2002;4(1):29-38. doi:10.1002/jtr.346

7. Trauer B. Conceptualizing special interest tourism-frameworks for analysis. Tour Manag. 2006;27(2):183-200. doi:10.1016/j. tourman.2004.10.004

8. MacLeod DV. Niche Tourism in Question: Interdisciplinary Perspectives on Problems and Possibilities. University of Glasgow Crichton Publications; 2003.

9. Morgan NJ, Pritchard A. Promoting niche tourism destination brands: case studies of New Zealand and Wales. J Promot Manag. 2006;12(1):17-33. doi:10.1300/J057v12n01_03

10. Novelli M. Niche Tourism: Contemporary Issues, Trends and Cases. Butterworth-Heinemann Ltd; 2005.

11. Poria Y, Butler R, Airey D. Links between tourists, heritage, and reasons for visiting heritage sites. J Travel Res. 2004;43 (1):19-28. doi:10.1177/0047287504265508

12. Gao J, Lin SS, Zhang C. Authenticity, involvement, and nostalgia: understanding visitor satisfaction with an adaptive reuse heritage site in urban China. J Dest Mark Manage. 2020;15:100404. doi:10.1016/j.jdmm.20190100404
13. Kulczycki C, Hyatt C. Expanding the conceptualization of nostalgia sport tourism: lessons learned from fans left behind after sport franchise relocation. J Sport Tour. 2005;10(4):273-293. doi:10.1080/14775080600805515

14. Lee CF, Chuang SC, Chiu CK, Lan KH. The influence of task difficulty on context effect-compromise and attraction effects. Curr Psychol. 2017;36(3):392-409. doi:10.1007/s12144-016-9428-0

15. Vesey C, Dimanche F. From Storyville to Bourbon street: vice, nostalgia and tourism. J Tour Cult Chang. 2003;1(1):54-70. doi:10.1080/14766820308668159

16. Jain V, Merchant A, Roy S, Ford JB. Developing an emic scale to measure ad-evoked nostalgia in a collectivist emerging market, India. $J$ Bus Res. 2019;99:140-156. doi:10.1016/j. jbusres.2019.02.039

17. Kim S, Kim S, Petrick JF. The effect of film nostalgia on involvement, familiarity, and behavioral intentions. J Travel Res. 2019;58 (2):283-297. doi:10.1177/0047287517746015

18. Merchant A, Ford JB, Dianoux C, Herrmann J-L. Development and validation of an emic scale to measure ad-evoked nostalgia in France. Int $J$ Advert. 2016;35(4):706-729. doi:10.1080/ 02650487.2015.1090049

19. Nguyen THH, Cheung C. Chinese heritage tourists to heritage sites: what are the effects of heritage motivation and perceived authenticity on satisfaction? Asia Pac J Tour Res. 2016;21 (11):1155-1168. doi:10.1080/10941665.2015.1125377

20. Park E, Choi B-K, Lee TJ. The role and dimensions of authenticity in heritage tourism. Tour Manag. 2019;74:99-109. doi:10.1016/j.tourman.2019.03.001

21. Zhang T, Yin P. Testing the structural relationships of tourism authenticities. $J$ Dest Mark Manage. 2020;18:100485. doi:10.1016/j.jdmm.2020.100485

22. Sedikides $\mathrm{C}$, Wildschut T. Finding meaning in nostalgia. Rev Gen Psychol. 2018;22(1):48-61. doi:10.1037/gpr0000109

23. Merchant A, Rose GM. Effects of advertising-evoked vicarious nostalgia on brand heritage. J Bus Res. 2013;66(12):2619-2625. doi:10.1016/j.jbusres.2012.05.021

24. Chi OH, Chi CG. Reminiscing other people's memories: conceptualizing and measuring vicarious nostalgia evoked by heritage tourism. J Travel Res. 2020;0047287520969904. doi:10.1177/ 0047287520969904

25. Izard CE. Human Emotions. Plenum Press; 1977.

26. Carey TC, Carey MP, Kelley ML. Differential emotions theory: relative contribution of emotion, cognition, and behavior to the prediction of depressive symptomatology in non-referred adolescents. J Clin Psychol. 1997;53(1):25-34. doi:10.1002/(SICI) 1097-4679(199701)53:13.0.CO;2-U

27. He M-X, Sha Z-Q, Zhou F. An empirical study on the impacts of retail agglomeration image on customer citizenship behavior. IEEE. 2013:903-908. Available from: https://ieeexplore-ieeeorg.univie.80599.net/abstract/document/6586385.

28. Izard CE. Basic emotions, relations among emotions, and emotion-cognition relations. Psychol Rev. 1992;99(3):561-565. doi:10.1037/0033-295x.99.3.561

29. Han H, Moon H, Kim W. The influence of international tourists' self-image congruity with a shopping place on their shopping experiences. J Hosp Tour Manag. 2019;41:101-109. doi:10.1016/j.jhtm.2019.08.003

30. Holak SL, Havlena WJ. Feelings, fantasies, and memories: an examination of the emotional components of nostalgia. $J$ Bus Res. 1998;42(3):217-226. doi:10.1016/S0148-2963(97)00 119-7

31. Hofer J. Medical Dissertation on Nostalgia. Anspach CK, editor. Vol. 2. The Johns Hopkins University Press; 1934.

32. Smeekes A. National nostalgia: a group-based emotion that benefits the in-group but hampers intergroup relations. Int J Intercult Relat. 2015;49:54-67. doi:10.1016/j.ijintrel.2015.07.001 
33. Christou P, Farmaki A, Evangelou G. Nurturing nostalgia?: a response from rural tourism stakeholders. Tour Manag. 2018;69:42-51. doi:10.1016/j.tourman.2018.05.010

34. Tsai C-T, Hsu H, Chen -C-C. An examination of experiential quality, nostalgia, place attachment and behavioral intentions of hospitality customers. J Hosp Mark Manag. 2020;29(7):869-885. doi:10.1080/19368623.2020.1706684

35. Sierra JJ, McQuitty S. Attitudes and emotions as determinants of nostalgia purchases: an application of social identity theory. J Mark Theor Prac. 2007;15(2):99-112. doi:10.2753/MTP10696679150201

36. Xiang K, Xu C, Wang J. Understanding the relationship between tourists' consumption behavior and their consumption substitution willingness under unusual environment. Psychol Res Behav Manag. 2021;14:483. doi:10.2147/PRBM.S303239

37. Zhang L. Unusual environments: re-study of core concepts of tourism-an attempt to construct a framework for tourism studies. Tour Tribune. 2009;7:12-17.

38. Frisvoll S. Conceptualising authentication of ruralness. Ann Tour Res. 2013;43:272-296. doi:10.1016/j.annals.2013.07.006

39. Hunt L, Johns $\mathrm{N}$, Ingram $\mathrm{H}$. Image, place and nostalgia in hospitality branding and marketing. Worldw Hosp Tour Themes. 2013;5(1):14-26. doi:10.1108/17554211311292411

40. Sedikides C, Wildschut T, Routledge C, Arndt J, Hepper EG, Zhou X. To nostalgize: mixing memory with affect and desire. Adv Exp Soc Psychol. 2015;51:189-273.

41. Kolar T, Zabkar V. A consumer-based model of authenticity: an oxymoron or the foundation of cultural heritage marketing? Tour Manag. 2010;31(5):652-664. doi:10.1016/j.tourman.2009.07.010

42. Qiao F, Choi Y, Lee TJ. Assessing feasibility of film-induced tourism: the case of Singapore. Int Tour Sci. 2016;16(3):93-105. doi:10.1080/15980634.2016.1163823

43. Ram Y, Björk P, Weidenfeld A. Authenticity and place attachment of major visitor attractions. Tour Manag. 2016;52:110-122. doi:10.1016/j.tourman.2015.06.010

44. Yoon Y, Uysal M. An examination of the effects of motivation and satisfaction on destination loyalty: a structural model. Tour Manag. 2005;26(1):45-56. doi:10.1016/j.tourman.2003.08.016

45. Jarratt D, Gammon S. 'We had the most wonderful times': seaside nostalgia at a British resort. Tour Recreat Res. 2016;41 (2):123-133. doi:10.1080/02508281.2016.1147213

46. Lu L, Chi CG, Liu Y. Authenticity, involvement, and image: evaluating tourist experiences at historic districts. Tour Manag. 2015;50:85-96. doi:10.1016/j.tourman.2015.01.026

47. Yi X, Fu X, Yu L, Jiang L. Authenticity and loyalty at heritage sites: the moderation effect of postmodern authenticity. Tour Manag. 2018;67:411-424. doi:10.1016/j.tourman.2018.01.013

48. Chhabra D. Defining authenticity and its determinants: toward an authenticity flow model. J Travel Res. 2005;44(1):64-73. doi: $10.1177 / 0047287505276592$

49. Moscardo G, Pearce PL. Understanding ethnic tourists. Ann Tour Res. 1999;26(2):416-434. doi:10.1016/S0160-7383(98)00101-7

50. Xie PF, Wall G. Visitors' perceptions of authenticity at cultural attractions in Hainan, China. Int J Tour Res. 2002;4(5):353-366. doi: $10.1002 /$ jtr.385

51. Di Domenico M, Miller G. Farming and tourism enterprise: experiential authenticity in the diversification of independent small-scale family farming. Tour Manag. 2012;33(2):285-294. doi:10.1016/j.tourman.2011.03.007

52. Rickly-Boyd JM. Authenticity \& aura: a Benjaminian approach to tourism. Ann Tour Res. 2012;39(1):269-289. doi:10.1016/j. annals.2011.05.003

53. Cook PS. Constructions and experiences of authenticity in medical tourism: the performances of places, spaces, practices, objects and bodies. Tour Stud. 2010;10(2):135-153. doi:10.1177/ 1468797611403048
54. Naoi T. Visitors' evaluation of a historical district: the roles of authenticity and manipulation. Tour Hosp Res. 2004;5(1):45-63. doi:10.1057/palgrave.thr.6040004

55. Beverland MB, Farrelly FJ. The quest for authenticity in consumption: consumers' purposive choice of authentic cues to shape experienced outcomes. J Cons Res. 2010;36(5):838-856. doi:10.1086/615047

56. Kim H, Jamal T. Touristic quest for existential authenticity. Ann Tour Res. 2007;34(1):181-201. doi:10.1016/j.annals.2006.07.009

57. Wang N. Rethinking authenticity in tourism experience. Ann Tour Res. 1999;2(26):349-370. doi:10.1016/S0160-7383(98)00103-0

58. Reisinger Y, Steiner CJ. Reconceptualizing object authenticity. Ann Tour Res. 2006;33(1):65-86. doi:10.1016/j.annals.2005.04.003

59. Yeoman I, Brass D, McMahon-Beattie U. Current issue in tourism: the authentic tourist. Tour Manag. 2007;28(4):1128-1138. doi:10.1016/j.tourman.2006.09.012

60. Lev Ari L, Mittelberg D. Between authenticity and ethnicity: heritage tourism and re-ethnification among diaspora Jewish youth. $J$ Herit Tour. 2008;3(2):79-103. doi:10.1080/ 17438730802138097

61. Belk RW. The role of possessions in constructing and maintaining a sense of past. $A C R N A m A d v$. 1990;17:669-676.

62. Davis F. Yearning for Yesterday: A Sociology of Nostalgia. Free Press; 1979.

63. Fairley S. In search of relived social experience: group-based nostalgia sport tourism. J Sport Manag. 2003;17(3):284-304. doi:10.1123/jsm.17.3.284

64. Holbrook MB. Nostalgia and consumption preferences: some emerging patterns of consumer tastes. J Cons Res. 1993;20 (2):245-256. doi:10.1086/209346

65. Holbrook MB, Schindler RM. Echoes of the dear departed past: some work in progress on nostalgia. ACR N Am Adv. 1991. Available from: https://web.b.ebscohost.com/abstract?direct= true \& profile $=$ ehost $\&$ scope $=$ site $\&$ authtype $=$ crawler $\&$ jrnl $=$ $00989258 \& \mathrm{~A} \mathrm{~N}=6522207 \& \mathrm{~h}=\mathrm{M} \mathrm{t} \mathrm{H} \mathrm{m} \mathrm{h} \mathrm{\%}$ 2fNomaxDNcL38AVHmgCWvuZEz45XjifKWgC87rNM30QojQ HrZEBOJzTqFLOSG\%2fIyaQ11IwhxRFfuUWA1Uw\%3d\% $3 \mathrm{~d} \& \mathrm{crl}=\mathrm{c} \&$ resultNs $=$ AdminWebAuth\&resultLocal $=$ ErrCrlNotAuth\&crlhashurl=login.aspx\%3fdirect $\% 3$ dtrue $\% 26$ pro file $\% 3$ dehost $\% 26$ scope $\% 3$ dsite $\% 26$ authtype $\% 3$ dcrawler $\% 26 j$ rnl \%3d00989258\%26AN\%3d6522207.

66. Hwang J, Hyun SS. The impact of nostalgia triggers on emotional responses and revisit intentions in luxury restaurants: the moderating role of hiatus. Int $J$ Hosp Manag. 2013;33:250-262. doi:10.1016/j.ijhm.2012.09.001

67. McIntosh A, Prentice R. Affirming authenticity. Consuming cultural heritage. Ann Tour Res. 1999;26(3):589-612. doi:10.1016/ S0160-7383(99)00010-9

68. Baldwin M, Biernat M, Landau MJ. Remembering the real me: nostalgia offers a window to the intrinsic self. J Pers Soc Psychol. 2015;108(1):128. doi:10.1037/a0038033

69. Park S, Hwang D, Lee WS, Heo J. Influence of nostalgia on authenticity, satisfaction, and revisit intention: the case of Jidong mural alley in Korea. Int J Hosp Tour Admin. 2020;21 (4):440-455. doi:10.1080/15256480.2018.1511497

70. Chen C-F, Chen F-S. Experience quality, perceived value, satisfaction and behavioral intentions for heritage tourists. Tour Manag. 2010;31(1):29-35. doi:10.1016/j.tourman.2009.02.008

71. Barr JC, Choi BK. How the West Sees Jeju: an analysis of westerners' perception of Jeju's personality as a destination. Int $J$ Tour Sci. 2016;16(3):135-149. doi:10.1080/ 15980634.2016.1248714

72. Schofield P. Evaluating castlefeeld urban heritage park from the consumer perspective: destination attribute importance, visitor perception, and satisfaction. Tour Anal. 2000;5(2-3):183-189. 
73. Del Bosque IR, San Martín H. Tourist satisfaction a cognitive-affective model. Ann Tour Res. 2008;35(2):551-573. doi:10.1016/j.annals.2008.02.006

74. Chon KS. Understanding recreational traveler's motivation, attitude and satisfaction. Tour Rev. 1989. doi:10.1108/eb058009

75. Francken DA, Van Raaij WF. Satisfaction with leisure time activities. $J$ Leis Res. 1981;13(4):337-352. doi:10.1080/ 00222216.1981 .11969498

76. Oliver RL. A cognitive model of the antecedents and consequences of satisfaction decisions. J Mark Res. 1980;17 (4):460-469. doi:10.1177/002224378001700405

77. Pedersen PE, Nysveen H. Shopbot banking: an exploratory study of customer loyalty effects. Int J Bank Mark. 2001. doi:10.1108/ 02652320110392518

78. Tse DK, Wilton PC. Models of consumer satisfaction formation: an extension. J Mark Res. 1988;25(2):204-212. doi:10.1177/ 002224378802500209

79. Chhabra D, Healy R, Sills E. Staged authenticity and heritage tourism. Ann Tour Res. 2003;30(3):702-719. doi:10.1016/S01607383(03)00044-6

80. Frost W. Braveheart-ed Ned Kelly: historic films, heritage tourism and destination image. Tour Manag. 2006;27(2):247-254. doi:10.1016/j.tourman.2004.09.006

81. Shen $\mathrm{S}$, Guo J, Wu Y. Investigating the structural relationships among authenticity, loyalty, involvement, and attitude toward world cultural heritage sites: an empirical study of Nanjing Xiaoling Tomb, China. Asia Pac J Tour Res. 2014;19 (1):103-121. doi:10.1080/10941665.2012.734522

82. Girish V, Chen C-F. Authenticity, experience, and loyalty in the festival context: evidence from the San Fermin festival, Spain. Curr Issues Tour. 2017;20(15):1551-1556. doi:10.1080/ 13683500.2017.1296821

83. Lee K-H, Yang G, Graham JL. Tension and trust in international business negotiations: American executives negotiating with Chinese executives. J Int Bus Stud. 2006;37(5):623-641. doi:10.1057/palgrave.jibs. 8400215

84. Hong JW, Zinkhan GM. Self-concept and advertising effectiveness: the influence of congruency, conspicuousness, and response mode. Psychol Mark. 1995;12(1):53-77. doi:10.1002/mar.4220120105

85. Han H, Back K-J. Relationships among image congruence, consumption emotions, and customer loyalty in the lodging industry. J Hosp Tour Res. 2008;32(4):467-490. doi:10.1177/ 1096348008321666

86. Ciarrochi J, Forgas JP. The pleasure of possessions: affective influences and personality in the evaluation of consumer items. Eur J Soc Psychol. 2000;30(5):631-649. doi:10.1002/1099-0992 (200009/10)30:5<631::AID-EJSP12>3.0.CO;2-T

87. Henseler J, Ringle C, Sinkovics R. The use of partial least squares path modeling in international marketing. Adv Int Mark. 2009 doi:10.1108/S1474-7979(2009)0000020014

88. Lee YZ. The pioneer of the Chinese Renaissance. J Shandong Univ. 2017;62(6):31-48.
89. Chin WW, Marcolin BL, Newsted PR. A partial least squares latent variable modeling approach for measuring interaction effects: results from a Monte Carlo Simulation Study and an electronic-mail Emotion/Adoption Study. Inf Sys Res. 2003;14 (2):189-217. doi:10.1287/isre.14.2.189.16018

90. Duarte P, Amaro S. Methods for modelling reflective-formative second order constructs in PLS. J Hosp Tour Technol. 2018. doi:10.1108/JHTT-09-2017-0092

91. Boomsma A, Hoogland JJ. The robustness of LISREL modeling revisited. In: Cudeck R, Toit SD, Sörbom D, editors. Structural Equation Modelling: Present and Future a Festschrift in Honor of Karl Jöreskog. Vol. 3. IL: Scientific Software International; 2001:139-168.

92. Ali F, Rasoolimanesh SM, Sarstedt M, Ringle CM, Ryu K. An assessment of the use of partial least squares structural equation modeling (PLS-SEM) in hospitality research. Int J Contemp Hosp Manag. 2018. doi:10.1108/IJCHM-10-2016-0568

93. Oviedo-García MÁ, Vega-Vázquez M, Castellanos-Verdugo M, Orgaz-Agüera F. Tourism in protected areas and the impact of servicescape on tourist satisfaction, key in sustainability. J Dest Mark Manage. 2019;12:74-83. doi:10.1016/j.jdmm.2019.02.005

94. Das G. Factors affecting Indian shoppers' attitude and purchase intention: an empirical check. J Retail Consum Serv. 2014;21 (4):561-569. doi:10.1016/j.jretconser.2014.04.005

95. Sirgy MJ, Su C. Destination image, self-congruity, and travel behavior: toward an integrative model. J Travel Res. 2000;38 (4):340-352. doi:10.1177/004728750003800402

96. Nunnally JC. An overview of psychological measurement. Clin Diagn Ment Disord. 1978;97-146.

97. Fornell C, Larcker DF. Evaluating structural equation models with unobservable variables and measurement error. J Mark Res. 1981;18(1):39-50. doi:10.1177/002224378101800104

98. Chin WW. The partial least squares approach to structural equation modeling. Mod Methods Bus Res. 1998;295(2):295-336.

99. Diamantopoulos A, Siguaw JA. Formative versus reflective indicators in organizational measure development: a comparison and empirical illustration. $B r \quad J$ Manage. 2006;17(4):263-282. doi:10.1111/j.1467-8551.2006.00500.x

100. Smith L, Campbell G. The tautology of "intangible values" and the misrecognition of intangible cultural heritage. Herit Soc. 2017;10(1):26-44. doi:10.1080/2159032X.2017.1423225

101. Shi Y, Bettache K, Zhang N, Xue L. Constructing nostalgia in tourism: a comparison analysis of genuine and artificial approaches. J Dest Mark Manage. 2021;19:100488. doi:10.1016/j.jdmm.2020.100488

102. Zhang S-N, Li Y-Q, Liu C-H, Ruan W-Q. How does authenticity enhance flow experience through perceived value and involvement: the moderating roles of innovation and cultural identity. J Travel Tour Mark. 2019;36(6):710-728. doi:10.1080/ 10548408.2019.1625846

\section{Publish your work in this journal}

Psychology Research and Behavior Management is an international peer-reviewed, open access journal focusing on the science of psychology and its application in behavior management to develop improved outcomes in the clinical, educational, sports and business arenas. Specific topics covered in the journal include: Neuroscience, memory and decision making; Behavior modification and management; Clinica applications; Business and sports performance management; Social and developmental studies; Animal studies. The manuscript management system is completely online and includes a very quick and fair peer-review system, which is all easy to use. Visit http://www dovepress.com/testimonials.php to read real quotes from published authors. 